\title{
Sciaridae (Diptera) from central Finland: faunistics and taxonomy
}

\author{
Jukka Salmela \& Pekka Vilkamaa
}

Salmela, J. \& Vilkamaa, P. 2005: Sciaridae (Diptera) from central Finland: faunistics and taxonomy. - Entomol. Fennica 16: 287-300.

Sciaridae (Diptera) from forest and mire habitats from three localities in central Finland were identified. The material consisted of 609 specimens belonging to 106 species. The following species were found as new to Finland: Bradysia subbetuleti, B. submoesta, B. subscabricornis, Corynoptera fera, C. furcifera, C. saetistyla, C. subsedula, Cratyna spiculosa, Leptosciariella helvetica, Lycoriella micria, Pseudolycoriella brunnea, P. nodulosa, Scatopsciara neglecta, Trichosia glabra and Sciara sp. n. (Menzel \& Salmela, in prep.) and Ctenosciara exigua sp. $\mathrm{n}$. The latter is described as new to science. Bradysia subbetuleti, Leptosciariella atricha, Leptosciariella tuberculigera and Lycoriella micria are redescribed. The occurrence of some rare or poorly known species is discussed, and the importance of peatlands for sciarid biodiversity in the boreal region is emphasized.

J. Salmela: Department of Biological and Environmental Sciences, P. O. Box 35, FI-40014 University of Jyväskylä, Finland; E-mail: jueesalm@cc.jyu.fi

P. Vilkamaa: Finnish Museum of Natural History, Zoological Museum, P. O. Box 17, FI-00014 University of Helsinki; E-mail: pekka.vilkamaa@helsinki.fi

Received 7 February 2005, accepted 8 March 2005

\section{Introduction}

Sciaridae (Diptera) are small and inconspicuous nematocerous flies which live in shaded or moist habitats, like forests. The larvae of most species are detritivorous, saproxylic, fungivorous or leaf miners (Irmler et al. 1996, Menzel \& Mohrig 2000, Komonen \& Vilkamaa 2001). In addition to purely terrestrial habitats, some species of Sciaridae are probably dependent on peat bogs and semiaquatic biotopes (eg. Rudzinski 1993, 1998). A few species are regarded as pests in greenhouses or mushroom farms (Menzel et al. 2003a).

Frey (1948), Tuomikoski (1957, 1960), Hippa and Vilkamaa (1991, 1994, 2004) Hippa et al.
(2003), and Vilkamaa et al. (2004) have studied the Sciaridae fauna of northern Europe, but these studies were almost entirely taxonomic in scope, and knowledge of the distribution and ecology of sciarids in Finland and northern Europe as a whole has remained very scarce. Our primary aim here was to provide new information on the faunistics of Sciaridae of Finland, based on the material collected recently from different localities in central Finland, so far almost entirely unknown for its sciarid fauna.

The taxonomy of most genera of Sciaridae occurring in the Palaearctic region have not been treated throroughly enough to guarantee the monophyly of genera, nor have all the species concepts been defined, although recently Menzel 
Table 1.Location and tree characteristics of window traps in Rautalampi. Tree species in all the cases Populus tremula.

\begin{tabular}{lllcrc}
\hline Trap & Location & Forest type & Snag/log & $\begin{array}{c}\text { Tree diam. } \\
(\mathrm{cm})\end{array}$ & $\begin{array}{c}\text { Cover of bark } \\
(\%)\end{array}$ \\
\hline WT6 & $6941: 484$ & old growth & snag & 25 & 90 \\
WT10 & $6941: 484$ & old growth & snag & 100 & 85 \\
WT12 & $6944: 484$ & clear-cut & snag & 70 & 55 \\
WT14 & $6940: 486$ & clear-cut & snag & 60 & 15 \\
WT17 & $6938: 487$ & clear-cut & snag & 35 & 40 \\
WT18 & $6933: 479$ & clear-cut & snag & 35 & 45 \\
WT19 & $6936: 472$ & clear-cut & log & 35 & 100 \\
\hline
\end{tabular}

and Mohrig (2000) have done much to clarify the nomenclature and found valid names for most species. Typical for any faunistic work on Sciaridae is that undescribed species are constantly found in samples. Even if this was not the case, the existing identification tools (mostly only the original descriptions) are not always good enough to be used to identify with any certainty the taxa found. Owing to the lack of reliable reference material, we have left some species of the taxonomically notorious genus Bradysia Winnertz found in our samples unidentified, for example those species of this genus which we could not reliably identify because our material was in such poor condition. Many groups treated here are currently being studied by us and our coworkers for their phylogeny and taxonomy, and changes in species concepts and in generic combinations are to be expected later.

In our view, some species in the collected material are difficult to identify using the existing literature or are in need of a redefinition. These are redescribed or diagnosed and illustrated here, and one species of Ctenosciara Tuomikoski is described as new to science. A new species of Sciara Meigen found in the material will be described elsewhere.

For the taxonomic treatment of the selected species, all available material has been used, not only that found on the central Finland sites. The authors are well aware of the drawbacks of treating only selected species without taking the broader taxonomic issues of the groups into account. However, there is an urgent need to have more information on the sciarid fauna of northern Europe as well as to publish diagnoses of the spe- cies to make them more easily identifiable in future studies, these species are redescribed here. Many others, which are listed in Table 5, certainly meet these criteria, but are currently under review and will be treated later.

\section{Material and methods}

Sciarids were collected in three municipalities in central Finland using three sampling methods: sweep netting, window traps and Malaise traps. In Rautalampi municipality, ten window traps were placed on decaying deciduous trees in a shaded forest (Kalajanvuori) and ten traps on deciduous trees in open clear-cut areas (Table 1; characteristics of the studied trees where sciarids were caught are presented). Kalajanvuori is an old growth, natural state forest characterized by a mixture of coniferous (Picea abies, Pinus sylvestris) and boreal deciduous trees (Populus tremula, Alnus, Betula) and relatively large amounts of decaying tree material, exceeding 20 $\mathrm{m}^{3} /$ ha. The surrounding clear-cut areas had some retained dead trees, mainly Betula and P. tremula and saplings of various tree species. The traps were set on the trees on 10 May and removed on 27 October 2003. Glycol (50:50) and few drops of detergent were used as a preservative in the traps and the traps were emptied at 2-4 week intervals. On one occasion in June 2003, flies were collected in Kalajanvuori forest by sweep netting. The collected material was stored in $70 \%$ ethanol, and the sciarids were later sorted out in the laboratory under a dissecting microscope.

In Konnevesi municipality, adult sciarids 
Table 2. Location and forest types of Konnevesi localities.

\begin{tabular}{lll}
\hline Location & $\begin{array}{l}\text { Forest } \\
\text { type }\end{array}$ & $\begin{array}{l}\text { Other } \\
\text { habitats }\end{array}$ \\
\hline $\begin{array}{l}\text { Siikakoski 6946:465 } \\
\text { Biol. station 6945:466 }\end{array}$ & MT & \\
Teerimäki 6941:468 & OMT & \\
Pukara S 6945:460 & MT & brook \\
Pukara N 6945:460 & MT & $\begin{array}{l}\text { spring } \\
\text { spring } \\
\text { Sauvonniemi 6938:464 }\end{array}$ \\
\hline
\end{tabular}

were collected by sweep netting from six spruce (Picea abies) dominated forests (Table 2). The collection sites were relatively uniform in terms of tree age (ca. 70 years), and the amount of coarse woody debris was ca. $1-3 \mathrm{~m}^{3} / \mathrm{ha}$. In four of the six sites, the collection took place also in the vicinity of a spring or brook (Table 2). The sampling was done in June and July 2003 on three occasions in an area about $150 \mathrm{~m}^{2}$ in each locality.
Table 3. Location and mire types of Malaise traps in Toivakka, Ruostesuo.

\begin{tabular}{lll}
\hline Trap & Location & Mire type \\
\hline 1 & $6886: 443$ & mesotrophic spring \\
2 & $6886: 443$ & tall-sedge pine fen \\
3 & $6886: 443$ & ordinary spruce-pine mire \\
4 & $6886: 443$ & ordinary spruce-pine mire \\
\hline
\end{tabular}

Flies were collected by sweeping lower vegetation, shrubs and tree branches, and the collected material was stored in ethanol in the field and sorted later.

To collect insects in Toivakka municipality, Ruostesuo mire, bilateral Malaise traps (length $110 \mathrm{~cm}$, height $140 \mathrm{~cm}$, width $70 \mathrm{~cm}$ ) were used. The area of the mire covers about 4 ha and includes diverse mire vegetation types, such as spruce mires, pine mires, swamps, fens, eutrophic fens and spring vegetation. All levels of minerotrophy occur in the mire: oligo-, meso-

Table 4. Species reported for the first time from Finland and their distribution in Palaearctic region.

\begin{tabular}{|c|c|c|c|}
\hline Species & Distribution & ${ }^{*}$ Finland & References \\
\hline Bradysia subbetuleti & Russian Far East & $\mathrm{Tb}$ & 1 \\
\hline Bradysia submoesta & $\begin{array}{l}\text { Lithuania, Russia, Czech Rep., Germany, } \\
\text { Switzerland, Estonia }\end{array}$ & $\mathrm{Tb}$ & $2,3,4,5,6$ \\
\hline Bradysia subscabricornis & $\begin{array}{l}\text { Great Britain, Germany, Austria, Netherlands, } \\
\text { Czech Rep. }\end{array}$ & $\mathrm{Tb}$ & $7,8,9,11$ \\
\hline Corynoptera fera & Germany & $\mathrm{Tb}$ & 12,13 \\
\hline Corynoptera furcifera & Russian Middle Asia, Germany, Bulgaria & $\mathrm{Tb}$ & $14,15,16$ \\
\hline Corynoptera saetistyla & $\begin{array}{l}\text { Russia, Germany, Austria, Hungary, } \\
\text { Czech Rep., Great Britain, Estonia }\end{array}$ & $\mathrm{Tb}$ & $\begin{array}{l}17,8,9,18 \\
19,20,7,6\end{array}$ \\
\hline Corynoptera subsedula & Russian Middle Asia & $\mathrm{Tb}$ & 14 \\
\hline Cratyna spiculosa & Germany, Netherlands, Great Britain, Estonia & $\mathrm{Tb}$ & $23,10,24,6$ \\
\hline Leptosciariella helvetica & Switzerland, Germany, Slovak rep. & $\mathrm{Tb}$ & 25 \\
\hline Lycoriella micria & Germany, Czech Rep. & $\mathrm{Tb}$ & 8,13 \\
\hline Pseudolycoriella brunnea & Switzerland, Ukraine, Turkey, Germany & $\mathrm{Tb}, \mathrm{Ta}, \mathrm{Ab}$ & $5,26,27,9$ \\
\hline Pseudolycoriella nodulosa & Germany, Austria, Czech Rep, Belarussia & $\mathrm{Tb}, \mathrm{St}$ & $15,19,20,28$ \\
\hline Scatopsciara neglecta & Central \& NW Europe, Great Britain & $\mathrm{Tb}$ & 29,7 \\
\hline Trichosia glabra & Austria, Great Britain, Germany, Denmark & $\mathrm{Tb}, \mathrm{St}, \mathrm{Li}$ & $19,30,7,31$ \\
\hline Ctenosciara exigua sp. n. & Finland & $\mathrm{Tb}, \mathrm{St}$ & this paper \\
\hline $\begin{array}{l}\text { Sciara sp. n. } \\
\text { (Menzel \& Salmela in prep) }\end{array}$ & Estonia & $\mathrm{Tb}$ & 6 \\
\hline
\end{tabular}

*Distribution in Finland, biogeographical provinces.

References: 1) Mohrig et al. 1989b, 2) Mohrig et al. 1989a, 3) Mohrig \& Menzel 1993, 4) Rudzinski 1993, 5) Menzel 1998b, 6) Menzel \& Salmela in prep, 7) Menzel 1998a, 8) Menzel et al. 1990, 9) Menzel 2001, 10) Menzel 2002, 11) Rudzinski 1998, 12) Heller \& Mohrig 1992, 13) Menzel et al. 2003b, 14) Mohrig \& Mamaev 1987, 15) Menzel 2000, 16) Dimitrova \& Mohrig 1993, 17) Mohrig et al. 1985a, 18) Rulik et al. 2001, 19) Rudzinski 1994a, 20) Rudzinski \& Košel 1997, 21) Mohrig et al. 1985c, 22) Freeman 1987, 23) Rudzinski 1993, 24) Laurence 1994, 25) Mohrig \& Menzel 1997, 26) Mohrig et al. 1979, 27) Rudzinski 1996, 28) Mohrig et al. 1985b, 29) Menzel \& Mohrig 1998, 30) Menzel \& Mohrig 1997, 31) Petersen \& Meier 2001. 
Table 5. Sciaridae collected from Central Finland in 2003. Species marked with * are new for Finland. Nomenclature follows Menzel and Mohrig (2000), Hippa et al. (2002), Vilkamaa (2000), Vilkamaa \& Hippa (2005).

1 = Ruostesuo; 2 = Siikakoski; 3 = Biol. Station; 4 = Teerimäki; 5 = Pukara S; 6 = Pukara N; 7 = Sauvonniemi;

$8=$ Kalajanvuori; 9 = Rautalampi WT.

\begin{tabular}{|c|c|c|c|c|c|c|c|c|c|}
\hline Site $\mathrm{nr}$ & 1 & 2 & 3 & 4 & 5 & 6 & 7 & 8 & 9 \\
\hline Bradysia aprica (Winnertz, 1867) & 2 & - & - & - & 1 & - & 1 & 4 & - \\
\hline Bradysia cinerascens (Grzegorzek, 1884) & 5 & - & - & - & - & - & - & - & - \\
\hline Bradysia fungicola (Winnertz, 1867) & - & - & - & - & - & - & 1 & - & - \\
\hline Bradysia hilariformis Tuomikoski, 1960 & - & - & 6 & 3 & 3 & 3 & 3 & - & - \\
\hline Bradysia globulifera (Lengersdorf, 1934) & 5 & - & - & - & - & - & - & - & - \\
\hline Bradysia longicubitalis (Lengersdorf, 1924) & 1 & - & - & - & - & - & - & - & - \\
\hline Bradysia nervosa (Meigen, 1818) & _ & 2 & - & - & _ & - & - & _ & _ \\
\hline Bradysia nocturna Tuomikoski, 1960 & 2 & - & - & - & - & - & - & - & - \\
\hline Bradysia placida (Winnertz, 1867) & - & - & - & - & - & - & - & - & 1 \\
\hline Bradysia rectinervis Frey, 1948 & 1 & - & - & 1 & - & - & - & - & - \\
\hline Bradysia regularis (Lengersdorf, 1934) & 7 & - & - & 1 & - & - & - & 2 & - \\
\hline Bradysia strigata (Staeger, 1840) & 1 & - & - & - & - & - & - & - & _ \\
\hline *Bradysia subbetuleti Mohrig \& Krivosheina, 1989 & - & - & - & 2 & - & - & - & 1 & - \\
\hline *Bradysia submoesta Mohrig \& Krivosheina 1989 & 1 & - & - & - & _ & - & - & _ & _ \\
\hline *Bradysia subscabricornis Mohrig \& Menzel, 1990 & 11 & - & - & - & - & - & - & - & - \\
\hline Bradysia spp. & 19 & 1 & 9 & 2 & 1 & 4 & 1 & 1 & - \\
\hline Bradysiopsis vittigera (Zetterstedt, 1851) & 5 & - & - & - & - & - & - & - & - \\
\hline Camptochaeta camptochaeta (Tuomikoski, 1960) & 3 & 12 & 7 & 3 & 1 & 6 & 5 & 4 & \\
\hline Camptochaeta hirtula (Lengersdorf, 1934) & - & - & 1 & 1 & 1 & 2 & - & 1 & _ \\
\hline Camptochaeta obscuripila (Tuomikoski, 1960) & - & - & - & - & - & - & - & 1 & - \\
\hline Camptochaeta sicilicula Hippa \& Vilkamaa 1994 & 1 & - & - & - & _ & - & - & _ & _ \\
\hline Camptochaeta spinifera Tuomikoski, 1960 & 3 & - & - & - & - & - & 1 & - & - \\
\hline Camptochaeta stammeri (Lengersdorf, 1940) & - & - & - & 1 & - & 1 & - & - & - \\
\hline Camptochaeta subdentata Mohrig, 1985 & - & 7 & 1 & 13 & 1 & 3 & 7 & 3 & \\
\hline Camptochaeta verrucifera (Lengersdorf, 1952) & 1 & - & - & - & - & - & - & - & - \\
\hline Camptochaeta vivax (Frey, 1948) & 1 & - & - & - & - & - & - & _ & _- \\
\hline Chaetosciara estlandica (Lengersdorf, 1929) & 13 & - & - & 3 & 1 & - & 5 & - & - \\
\hline orticis (Mohrig \& Antonowa, 1978) & 1 & - & - & - & - & - & - & - & - \\
\hline Corynoptera barbata Tuomikoski, 1960 & 13 & - & - & - & - & - & 1 & - & - \\
\hline Corynoptera blanda (Winnertz, 1867) & 6 & 3 & 3 & 2 & 2 & 3 & 4 & 2 & - \\
\hline Corynoptera boletiphaga (Lengersdorf, 1940) & 2 & 3 & - & 1 & 1 & 1 & 3 & 3 & _- \\
\hline${ }^{*}$ Corynoptera fera Mohrig \& Heller, 1992 & 1 & - & - & - & - & - & - & - & - \\
\hline Corynoptera cf forcipata (Winnertz, 1867) & - & - & - & 1 & - & - & - & - & \\
\hline *Corynoptera furcifera Mohrig \& Mamaev, 1987 & 1 & - & - & - & - & - & - & - & - \\
\hline Corynoptera hypopygialis (Lengersdorf, 1926) & 2 & 1 & 1 & - & - & - & 1 & - & - \\
\hline Corynoptera luteofusca (Bukowski \& Lengersdorf, 1936) & 1 & - & - & 1 & - & - & - & - & - \\
\hline Corynoptera $p$ & 2 & - & - & - & - & - & - & - & \\
\hline Corynoptera saccata Tuomikoski, 1960 & 2 & - & - & - & - & - & - & - & \\
\hline${ }^{*}$ Corynoptera saetistyla Mohrig \& Krivosheina, 1985 & 2 & - & - & - & - & - & 2 & - & - \\
\hline *Corynoptera subsedula Mohrig \& Mamaev, 1987 & - & - & - & - & - & - & - & 1 & _ \\
\hline Corynoptera trepida (Lengersdorf, 1929) & 4 & 1 & 1 & 2 & 1 & 1 & 3 & 1 & - \\
\hline Corynoptera tetr & 1 & - & - & - & - & - & - & - & \\
\hline Corynoptera triacantha Tuomikoski, 1960 & 1 & - & - & - & - & - & - & _ & _ \\
\hline Corynoptera vagula Tuomikoski, 1960 & 6 & - & - & - & - & - & - & - & - \\
\hline Corynoptera spp. & 6 & - & - & - & - & - & - & - & \\
\hline Cratyna (C.) uliginosa (Lengersdorf, 1929) & 8 & - & - & - & 3 & 3 & 2 & 3 & \\
\hline${ }^{*}$ Cratyna (Diversicratyna) spiculosa (Rudzinski, 1993) & 1 & - & - & - & 1 & - & - & - & - \\
\hline Cratyna (Spathobdella) falcifera (Lengersdorf, 1933) & 7 & - & - & - & - & - & - & - & - \\
\hline Cratyna (S.) nobilis (Winnertz, 1867) & 9 & 3 & 1 & 5 & - & 2 & 2 & - & - \\
\hline Cratyna (S.) perplexa (Winnertz, 1867) & - & - & - & - & - & 1 & - & _ & \\
\hline Ctenosciara hyalipennis (Meigen, 1804) & 35 & - & - & - & 2 & 2 & 3 & - & \\
\hline Ctenosciara exigua sp. n. & 2 & - & - & - & - & - & - & - & \\
\hline
\end{tabular}




\begin{tabular}{lllllllllll}
\hline Site $\mathrm{nr}$ & 1 & 2 & 3 & 4 & 5 & 6 & 7 & 8 & 9 \\
\hline
\end{tabular}

Dichopygina aculeata Vilkamaa, Hippa \& Komarova 2004

Dolichosciara flavipes (Meigen, 1804)

Dolichosciara orcina (Tuomikoski, 1960)

Dolichosciara ornata (Winnertz, 1867)

Dolichosciara saetosa (Lengersdorf, 1929)

Epidapus (E.) alnicola (Tuomikoski, 1957)

Epidapus (E.) atomarius (De Geer, 1778)

Keilbachia ferrata (Hippa \& Vilkamaa, 1994)

Leptosciariella (Hirtipennia) hirtipennis (Zetterstedt, 1838)

Leptosciariella (L.) dimera (Tuomikoski, 1960)

Leptosciariella (L.) fuscipalpa (Mohrig \& Mamaev, 1979)

*Leptosciariella (L.) helvetica (Rudzinski, 1992)

Leptosciariella (L.) nudinervis (Tuomikoski, 1960)

Leptosciariella (L.) scutellata (Staeger, 1840)

Leptosciariella (Leptospina) atricha (Tuomikoski, 1960)

Leptosciariella (Trichosiopsis) tuberculigera

(Tuomikoski, 1960)

Lycoriella (Hemineurina) globiceps (Becher, 1886)

Lycoriella (L.) ingenua (Dufour, 1839)

Lycoriella (L.) lundstromi (Frey, 1948)

Lycoriella (L.) latilobata Menzel \& Mohrig 2000

Lycoriella (L.) sp.

*Lycoriella (L.) micria Mohrig \& Menzel, 1990

Peyerimhoffia crassistylata (Frey, 1948)

Peyerimhoffia vagabunda (Winnertz, 1867)

Prosciara plusiochaeta Hippa \& Vilkamaa, 1991

Prosciara porrecta (Lengersdorf, 1929)

Prosciara prosciarioides (Tuomikoski, 1960)

*Pseudolycoriella brunnea (Bukowski \& Lengersdorf, 1936)

${ }^{*}$ Pseudolycoriella nodulosa (Mohrig \& Krivosheina, 1985)

Pseudolycoriella paludum (Frey, 1948)

Scatopsciara (S.) calamophila Frey, 1948

Scatopsciara (S.) cf. nacta (Johanssen, 1912)

*Scatopsciara (S.) negleta Menzel \& Mohrig, 1998

Scatopsciara (S.) pusilla (Meigen, 1818)

Scatopsciara (S.) tricuspidata (Winnertz, 1867)

Scatopsciara (S.) sp.

Scatopsciara (Xenopygina) simillima (Tuomikoski, 1960)

Sciara helveola Winnertz, 1867

Sciara thoamae (Linnaeus, 1767)

Sciara humeralis Zetterstedt, 1851

Sciara lackschewitzi (Lengersdorf, 1934)

*Sciara sp. n. Menzel \& Salmela (in prep.)

Trichosia (T.) acrotricha Tuomikoski, 1960

Trichosia (T.) splendens Winnertz, 1867

${ }^{*}$ Trichosia (T.) glabra (Meigen, 1830)

Trichosia (T.) morio (Fabricius, 1794)

Xylosciara (Protoxylosciara) longiforceps

(Bukowski \& Lengersdorf, 1936)

Xylosciara (X.) betulae Tuomikoski, 1960

Xylosciara (X.) heptacantha Tuomikoski, 1960

Xylosciara $(X$.$) lignicola (Winnertz, 1867)$

Xylosciara (X.) misella (Frey, 1948)

Xylosciara (X.) phryganophila (Frey, 1948)

Xylosciara (X.) steleocera Tuomikoski, 1960

Zygoneura sciarina Meigen, 1830

\begin{tabular}{|c|c|c|c|c|c|c|c|c|}
\hline 7 & - & - & - & - & - & - & - & \\
\hline 2 & - & - & - & - & - & - & 1 & \\
\hline$Z$ & - & - & - & - & - & - & - & . \\
\hline & - & - & - & - & - & - & - & \\
\hline & - & - & & & - & - & - & . \\
\hline 1 & - & - & - & - & - & - & - & . \\
\hline 2 & - & - & 1 & - & 1 & - & - & . \\
\hline- & - & - & - & - & 1 & - & - & - \\
\hline- & - & - & - & - & - & - & 1 & \\
\hline & - & - & - & - & - & - & - & . \\
\hline 1 & - & - & - & - & - & - & - & . \\
\hline- & - & - & - & - & 1 & - & - & - \\
\hline- & 1 & - & - & - & - & - & - & - \\
\hline- & - & - & - & - & - & - & 1 & \\
\hline & - & 1 & - & - & - & - & 1 & . \\
\hline- & - & - & - & - & 2 & - & - & - \\
\hline 1 & 2 & - & 1 & - & - & - & - & \\
\hline 1 & - & - & - & - & - & - & - & \\
\hline 8 & - & 1 & - & & - & - & 2 & \\
\hline - & - & - & - & 1 & - & - & - & - \\
\hline 4 & - & - & - & - & - & - & - & - \\
\hline- & - & - & - & - & - & - & - & \\
\hline- & - & - & 2 & - & - & - & - & - \\
\hline 1 & - & 4 & - & - & - & - & - & - \\
\hline 1 & - & - & - & - & - & - & - & - \\
\hline 6 & - & - & - & - & - & - & - & - \\
\hline- & - & - & 1 & - & - & - & - & . \\
\hline 1 & - & - & - & - & - & - & - & - \\
\hline 1 & - & - & - & - & - & - & - & - \\
\hline 4 & - & - & - & - & - & - & - & \\
\hline- & - & - & 1 & - & - & 1 & - & - \\
\hline- & 12 & - & - & 2 & - & - & - & \\
\hline 1 & - & - & 1 & - & 1 & - & - & . \\
\hline 1 & - & - & - & - & - & - & - & - \\
\hline- & - & - & - & - & - & - & 1 & $\varepsilon$ \\
\hline - & - & - & 3 & - & 1 & - & 1 & . \\
\hline 8 & - & - & - & 1 & - & - & - & 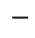 \\
\hline 6 & - & - & - & - & - & - & 1 & - \\
\hline 1 & - & - & - & - & - & - & - & - \\
\hline 1 & - & - & - & - & - & - & - & - \\
\hline 2 & - & - & - & - & - & - & - & \\
\hline 5 & - & - & - & - & - & - & - & . \\
\hline 1 & - & 1 & - & 1 & - & - & - & \\
\hline - & - & - & - & 3 & - & 1 & - & \\
\hline 1 & - & - & - & - & - & - & - & - \\
\hline 3 & - & - & 1 & - & - & - & - & \\
\hline- & - & 1 & - & - & - & - & - & . \\
\hline 3 & - & - & - & - & - & - & - & \\
\hline 1 & - & 1 & - & - & - & - & - & - \\
\hline 2 & - & - & - & - & - & - & - & \\
\hline 1 & - & - & - & - & - & - & - & \\
\hline & - & - & - & - & - & - & - & \\
\hline & - & 1 & - & 1 & - & - & - & \\
\hline 1 & - & - & 2 & - & - & 5 & - & \\
\hline
\end{tabular}


and eutrophy (Salonen \& Kovanen 1983). Ground water seepage in the southern part of the Ruostesuo mire and the small brooks flowing through the mire greatly enhances the diversity of mire vegetation. Four Malaise traps were set in the Ruostesuomire on 3 May and removed on 18 October 2003. Trap 1 was put in the highest part of the mire, where percolating ground water forms a helocrene spring. Traps 2 and 3 were set in the immediate vicinity of the brooks flowing through the mire, downstream from the spring area, and trap 4 on the shore of small Lake VähäIilijärvi (Table 3). The mire area studied here is surrounded by spruce mires, spruce forests and pine forests. A solution of $50 \%$ glycol plus a few drops of detergent was used as preservative in the traps. The traps were emptied monthly and the material was placed in $70 \%$ ethanol to be later sorted in the laboratory. The sciarids were mounted on microscope slides in Euparal, either directly after dehydration in absolute ethanol or after treating them first with potassium hydroxide $(\mathrm{KOH})$. The illustrations were made with the help of a drawing tube attached to a Leitz Diaplan compound microscope. The material studied in this paper is kept in the following collections: Deutsches Entomologisches Institut, Müncheberg (DEI), Private Collection of Jukka Salmela (PCJS) and Zoological Museum, Finnish Museum of Natural History, Helsinki (MZH).

The nomenclature generally follows Menzel and Mohrig (2000). In its new, monophyletic concept, Peyerimhoffia Kieffer is treated as a genus, not as a subgenus of Cratyna Winnertz (Vilkamaa \& Hippa 2005). The C. parvula species group is included in Camptochaeta, following Hippa \& Vilkamaa (1994), not in Corynoptera. Dolichosciara Tuomikoski and Prosciara Frey are treated as valid genera, not as subgenera of Phytosciara Frey, following Vilkamaa (2000). Sciara thomae (Linnaeus, 1767), not Sciara hemerobioides (Scopoli, 1763), is, according to Article 23.9.2. of the current Fourth Edition of International Code of Zoological Nomenclature (ICZN 1999), regarded as the valid name for the species.

\section{Results and discussion}

\subsection{Faunistics}

A total of 106 species of Sciaridae were identified (Table 5). The Ruostesuo mire locality was richest in species (site 1; 76 spp.), followed by the Konnevesi spruce forest localities (sites 2-7; together $55 \mathrm{spp}$.) and the Rautalampi (sites 8 and 9; $21 \mathrm{spp}$.). Common species, which occurred at least on four study sites (Table 4), were Bradysia hilariformis, Camptochaeta camptochaeta, C. hirtula, Chaetosciara estlandica, Corynoptera blanda, C. boletiphaga, C. hypopygialis, C. subdentata, C. trepida, Cratyna nobilis, C. uliginosa, Ctenosciara hyalipennis and Lycoriella lundstro$m i$. According to Tuomikoski (1960), C. camptochaeta is a very common species in "shaded forests" during early summer, and there are several records from different parts of Finland (Hippa \& Vilkamaa 1994). Bradysia hilariformis may be a relatively southern species in Finland (Tuomikoski 1960, J. Salmela, unpubl.), and the localities of the present study are the northernmost records so far in the country. In contrast, $C$. hirtula, C. boletiphaga, C. hypopygialis, C. trepida, $C$. subdentata, $C$. nobilis, $C$. hyalipennis and $L$. lundstromi are also found in the northern parts of the country (Tuomikoski 1960, Hippa \& Vilkamaa 1994, Salmela \& Vilkamaa, in prep.). Chaetosciara estlandica may also be a southern species in Finland, and its preferred habitats seem to be moist forests and mires (Tuomikoski 1960). In this study, C. estlandica was caught on sites characterized by Sphagnum mosses (Ruostesuo) or other moist conditions (springs and brooks, Table 2).

The following species were caught only in window traps placed on decaying trees: Bradysia placida (trap 14), Lycoriella micria (trap 10), Scatopsciara tricuspidata, Scatopsciara sp. (trap 12). and Xylosciara phryganophila. According to Tuomikoski (1960 and the references therein) $S$. tricuspidata is saproxylic (or subcorticolous), living in both deciduous and coniferous wood. In the Rautalampi study area, S. tricuspidata was observed in shaded old growth forest and in open clear-cut areas in traps 6, 12, 14 and 17. Xylosciara phryganophila, like other species of Xylosciara (Hippa \& Vilkamaa 2004), is also most 
probably a saproxylic or subcorticolous species. It was found in the clear-cuts (traps 18 and 19). In general, only a few species were caught in window traps and no direct comparison can be made between the number of species in the old-growth forest and the clear-cut areas.

Sixteen species are reported here for the first time from Finland: Bradysia subbetuleti, B. submoesta, B. subscabricornis, Corynoptera fera, $C$. furcifera, C. saetistyla, C. subsedula, Cratyna spiculosa, Leptosciariella helvetica, Lycoriella micria, Pseudolycoriella brunnea, P. nodulosa, Scatopsciara neglecta, Trichosia glabra, Sciara sp. n. (Menzel \& Salmela in prep.) and Ctenosciara exigua sp. n. (see the description below). For the details of the distribution of these species, see Table 4.

In addition to the species found for the first time from Finland, some other little-known species were also identified. Among these, Leptosciariella (Trichosiopsis) tuberculigera, Prosciara plusiochaeta, Camptochaeta sicilicula and Corynoptera vagula were found in Finland for the second time since they were first described from Finnish materials (Tuomikoski 1960, Hippa \& Vilkamaa 1991, Hippa \& Vilkamaa 1994). C. verrucifera has been occasionally found in southern Finland (Hippa \& Vilkamaa 1994) whereas Claustropyga corticis is in Finland known only from one northern locality (Hippa et al. 2003). Two other rarely caught sciarids are perhaps worth mentioning: Keilbachia ferrata, which is known from Finland and Japan only [Hippa \& Vilkamaa (1994); as Camptochaeta ferrata] and Prosciara porrecta, which in Finland has been earlier reported from one locality (Tuomikoski 1960, Hippa \& Vilkamaa 1991). One should, however, bear in mind that we have little knowledge of the distribution and ecology of sciarids in Finland, and further studies are needed to classify species either as rare or common, and to understand their distribution.

A relatively high number of Sciaridae, 76 species, were found at Ruostesuo, which is a mire composed of diversity of different mire types (see Material and methods). According to the results obtained, wooded peatlands like the Ruostesuo mire may support a high diversity of sciarids, including species that may be more numerous in peatland habitats than in forest habitats. Mire dwelling sciarids are not well known, but some species, such as Bradysia strigata, Dolichosciara orcina, D. ornata, D. saetosa and Prosciara porrecta, may be abundant in peatlands (Frey 1948, Tuomikoski 1960, Mohrig \& Menzel 1994, Rudzinski 1998). In addition, our unpublished records from Finland and Estonia indicate that Pseudolycoriella nodulosa, Trichosia glabra, Ctenosciara exigua sp. n. and Sciara sp. n. (Menzel \& Salmela, in prep.) prefer mires or are dependent on wet peatlands.

Because of the different sampling efforts in the different habitats in our study, no direct comparison between the sciarid faunas of the forest and peatlands is possible, and the diversity of the forest localities is certainly underestimated. However, the astonishingly high number of species of Sciaridae found in the present mire habitats would indicate the importance of the natural state peatlands in the overall diversity of the sciarid fauna of the boreal region, even if the diversity in the forests is no doubt higher. Concerning the sciarid fauna of coniferous forests, although itself insufficiently known, it is far better known than that of bogs and mires, so there is an even greater need to study peatland faunas. This need is urgent, because, due to forestry and agriculture, the area and quality of the natural state mires in Finland has strongly declined (Aapala \& Lindholm 1995).

\subsection{Taxonomy}

\section{Leptosciarella (Trichosiopsis) tuberculigera (Tuomikoski, 1960)}

Trichosiopsis tuberculigera Tuomikoski, 1960: 28.

Leptosciarella (Trichosiopsis) tuberculigera, Mohrig and Menzel 1997

Material examined. Holotype male: Finland, Ab, Vihti, Vihtijärvi, 16.VI.1958, R. Tuomikoski $(\mathrm{MZH})$. Other material: Finland, Tb, Konnevesi, Pukara (6945:460), 11.VI.2003, J. Salmela, 1 o (PCJS), same data but 21.VI.2003, 1 §ิ (PCJS), Lk, Rovaniemi, Pisavaara, 30.VI.1964, R. Tuomikoski, 1 ô (MZH), Li, Inari, Sarmitunturi wilderness area (7619579:3555405) 6.VII.-1.VIII. 2004, J. Salmela, 1 $\widehat{\text { T }}$ (PCJS), same locality but by a brook, 3.VI.-6.VII.2004, J. Salmela, $1 \hat{\sigma}$ 


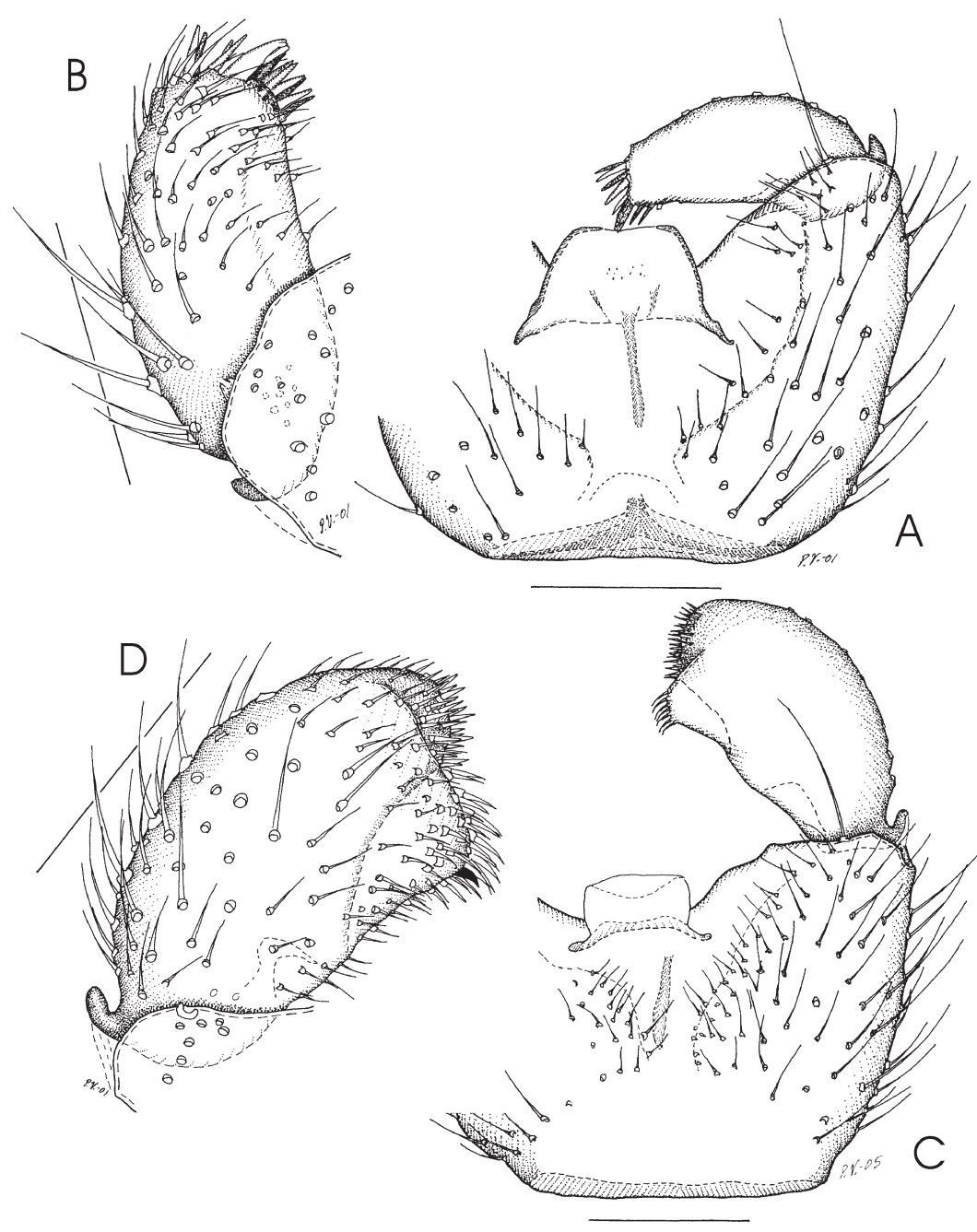

Fig. 1. Part of hypopygium ( $A$ and $C$ ) and gonostylus ( $B$ and $D$ ), ventral view. $-A$ and $B$ : Leptosciarella (Leptospina) atricha (Tuomikoski) (A from Finland, D lectotype). - C and D: Leptosciarella (Trichosiopsis) tuberculigera (Tuomikoski) (from Finland). Scale $0.10 \mathrm{~mm}$.

\section{(PCJS).}

Description. See also Tuomikoski (1960), Mohrig and Menzel (1997) and Menzel and Mohrig (2000).

Male. Head. Eye bridge with 2-3 rows of facets. Anterior vertex non-setose, prefrons with 12 17 setae, clypeus non-setose. Antennal flagellum long; length/width of flagellomere 4 1.60-2.25. Maxillary palp with three palpomerees; palpomere 1 with 3-5 setae, sensillae scattered on dorsal side. Thorax. Dark; notal setae pale. Episternum 1 with 2-3 setae. Wing. Length 1.8$2.1 \mathrm{~mm}$, width/length 045 . c/w 0.75, R1/R 1.151.20. Wing membrane non-setose, veins $M$ and $\mathrm{CuA}$ non-setose, hind margin with dorsal and ventral setae. Legs. Pale. T1 with subapical prolateral patch of pale setae, not in depression.
Abdomen. Yellowish brown, setae pale. Hypopygium, see Fig. 1C-D. Gonostylus with tiny apical tooth in the ventral lobe. Sternite 10 with 1 seta on each half.

Discussion. Tuomikoski (1960) based his monotypic genus Trichosiopsis on this species, and later Mohrig \& Menzel (1997) regarded Trichosiopsis as a subgenus of their redefined Leptosciarella Tuomikoski. L. tuberculigera resembles other species of Leptosciarella by having stout spine-like megasetae at the apex of gonostylus. It differs strongly by having a characteristic large, apically broad gonostylus, divided into distinct ventral and dorsal lobes. The ventral lobe is produced strongly mesiad and bears a tiny sharp apical tooth (Fig. 1D) that was overlooked by Tuomikoski himself (1960) and the later revi- 
sors (Mohrig \& Menzel 1997, Menzel \& Mohrig 2000). The species has so far been found only in Finland.

\section{Leptosciarella (Leptospina) atricha (Tuomi- koski, 1960)}

Trichosia (Leptosciarella) atricha Tuomikoski, 1960: 27.

Leptosciarella (Leptospina) atricha Mohrig \& Menzel 1997

Material examined. Lectotype male (des. Menzel in Mohrig \& Menzel 1997): Finland, Lk, Sodankyla. Korvanen, Mutenia, 30.VII.1958. Other material: Finland, Tb, Konnevesi, Kalajanvuori (6941:484), 31.VII. 2003, J. Salmela, 1 ^ PCJS), same data but Teerimäki (6941:468), 26.VII.2003, 1 సे (MZH), Tb, Konnevesi, Biol. Sta. (6945:466), 26.VII.2003, J. Salmela, 1 đิ (PCJS), Tb, Toivakka, Ruostesuo (6886:3443), Malaise trap, 1.-29.VII.2003, J. Salmela, 1 ภ (PCJS), Ta, Somero, Koisthuhta,

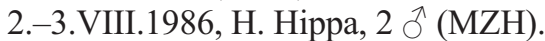

Description. See also Tuomikoski (1960), Mohrig and Menzel (1997) and Menzel and Mohrig (2000).

Male. Head. Eye bridge with 3 rows of facets. Anterior vertex non-setose, prefrons with 8-9 setae, clypeus with 1 seta. Antennal flagellum long; length/width of flagellomere 4 2.05-2.25. Maxillary palp with 3 segments; palpomeree 1 with 2 setae, sensillae scattered on dorsal side. Thorax. Dark; notal setae pale. Episternum 1 with 4-6 setae. Wing. Length $1.8-2.0 \mathrm{~mm}$, width/ length 0.45 . c/w $0.55-0.60, \mathrm{R} 1 / \mathrm{R}$ 1.05-1.35. Membrane non-setose, veins $\mathrm{M}$ and $\mathrm{CuA}$ without dorsal setae, R5 with ventral setae. Hind margin without ventral setae. Legs. Pale brown. T1 with subapical retrolateral patch of dark modified setae. Tibiae with strong dark spinose setae. Tarsal claws without teeth. Abdomen. Yellowish brown, setae pale. Hypopygium, see Fig. 1A-B. Sternite 10 with 1 seta on each half.

Discussion. Leptosciarella (Leptospina) atricha has up till now been known only from the type specimens. The above description is based on the lectotype and six additional males, four of which were found on the present study sites (Table 4). L. atricha is similar to other three known species of Leptospina by having at least part of the lateral (i.e. on the dorsal side of the apical tooth) megasetae of gonostylus strong. It differs from all other species of the subgenus by having all the dorsal megasetae (four) subequally strong and by having a group of subapical megasetae on its gonostylus (see Fig. 1B and Mohrig \& Menzel 1997: figures 34-37). Furthermore, the apical tooth of $L$. atricha is peculiar in structrure in being blunt and as if formed by longitudinal lobes (Fig. 1B), not sharp and compact like the apical tooth of other species of Leptosciarella. Whether other species of Leptosciarella (Leptospina) have this kind of apical tooth cannot be judged from the original descriptions or redescriptions (Mohrig \& Menzel 1997). L. atricha has also in the intercoxal area of its hypopygium a short, sclerotized septum, unknown in other species of the genus (Fig. 1A). It is considerably smaller than other species of Leptosciarella (Leptospina) (Mohrig \& Menzel 1997).

Female. Unknown.

\section{Lycoriella (Lycoriella) micria Mohrig \& Men- zel, 1990}

Lycoriella (Lycoriella) micria Mohrig \& Menzel in Menzel, Mohrig \& Groth, 1990: 342.

Material examined. Finland, Tb, Rautalampi, Kalajanvuori (6941:484), window trap on dead aspen, 17.VI.-20.VII.2003, J. Salmela, 1 ठ (PCJS), Germany, Brandenburg, Landkreis Barnim, Grumsin, Blocksberg, eclector trap, 19.IX.1999, Schulz \& Taeger, 1 đ (DEI), Czech Republic, Bilina-Holibka, 503120 N, 134940 $\mathrm{E}$, stony steppe, $450 \mathrm{~m}$, emergency trap, 24.VII.23.IX.1998, Barták, 1 § (DEI).

Description. See also Menzel et al. (1990).

Male. Head. Eye bridge with 2 rows of facets. Anterior vertex non-setose, setae of prefrons and clypeus not clearly visible in the specimens studied. Antennal flagellum long; length/width of flagellomere $42.05-2.90$. Maxillary palp with 23 palpomerees, basal palpomeree with 2 setae, sensilla in pit. Thorax. Pale brown, nota lsetae pale; anterior pronotum with 2-4 setae, episternum 1 with 4-5 setae. Wing. Length 0.9$1.1 \mathrm{~mm}$, width/length $0.35-0.45$. c/w 0.0 .70 , R1/R 0.60. Anal lobe weak. Legs pale. Tarsal claws without teeth. Abdomen. Yellowish, setae pale. Hypopygium. Fig. 2A and B. Sternite 10 

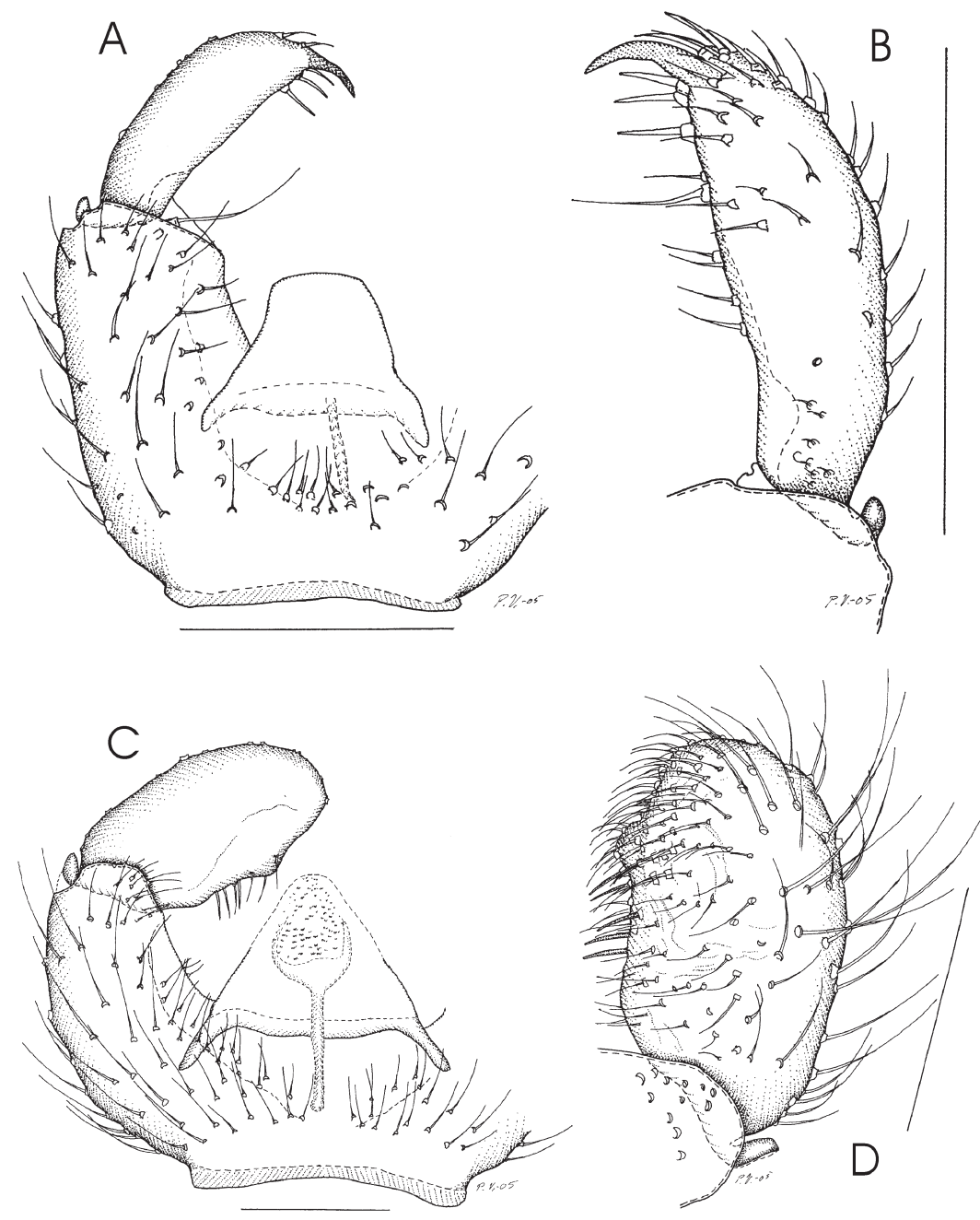

Fig. 2. Part of hypopygium ( $A$ and $C$ ) and gonostylus ( $B$ and $D)$, ventral view. - A-B. Lycoriella micria Mohrig \& Menzel (from Finland). - C-D. Bradysia subbetuleti Mohrig \& Krivosheina (from Finland). Scale bar $0.10 \mathrm{~mm}$.

with 1 seta on each half.

Female. Unknown.

Discussion. Lycoriella micria was described from the holotype male from Germany and a paratype male from the Czech Republic (Menzel et al. 1990). We have not seen the type material, and the above description is based on the three non-type specimens listed above. Lycoriella micria is very similar to Lycoriella deserticola (Mohrig \& Mamaev, 1983) from Uzbekistan (Mohrig et al. 1983). The concepts of these species are difficult to judge on the basis of the available material. Menzel et al. (1990) stated that $L$. micria has longer subapical megasetae on the gonostylus, shorter antennal flagellomeres, a three-segmented, not two-segmented maxillary palp, and longer wings (lengths not given). The
Finnish specimen of L. micria (Fig. 2A-B) seems to have shorter megasetae in relation to the apical tooth than the German one(s) have, but still longer than L. deserticola, as illustrated in the original descriptions. The number of megasetae might not be decisive: The type specimens of L. micria have three, $L$. deserticola two megasetae on both gonostyli, and the new Czech specimen two on the left, three on the right gonostylus. The German specimen studied here has the apical segment of the maxillary palp partly reduced and fused into the subapical one, similar to $L$. deserticola, and the Czech specimen has fairly long antennal flagellomeres (L/W ratio 2.90), even longer than $L$. deserticola (L/W 2.4, versus hardly two times as long as wide in the types of $L$. micria). Furthermore, the Finnish specimen has a 
similar group of slightly elongated setae as $L$. deserticola in the intercoxal area, not indicated in the original description of L. micria. Based on these characters, it may be that only one variable species is concerned, but as we have not seen the types of either species, we follow the existing concepts here (Menzel et al. 1990, Menzel \& Mohrig 2000).

There is no doubt that both species belong to Lycoriella s.str., having a slender gonostylus with slender apical tooth, slender subapical megasetae and a mediocentral flagellate seta; the fore tibial patch in depression, sensilla of maxillary palp in pit, and pale and faint setosity of the thorax and abdomen.

\section{Bradysia subbetuleti Mohrig \& Krivosheina, 1989}

Bradysia subbetuleti Mohrig \& Krivosheina in Mohrig, Krivosheina \& Mamaev, 1989: 433.

Material examined. Finland, Tb, Konnevesi, Sauvonniemi 6938:464, 22.VIII.2003, J. Salmela, 1 đ̊ (PCJS), Tb, Konnevesi, Teerimäki (6941:468), 29.VIII.2003, J. Salmela, $2 \pi$ (PCJS).

Description. See also Mohrig et al. (1989); in the following redescription, figures in brackets from the original description.

Male. Head. Eye bridge with 2-3(4) rows of facets. Anterior vertex non-setose, prefrons with 17-26 setae, clypeus with 1 seta. Antennal flagellum long; length/width of flagellomere 4 3.25 (3.0). Maxillary palp, with 3 palpomerees; palpomeree 1 with 3-4 setae, sensilla in patch. Thorax. Dark brown; anterior pronotum with 4 setae, episternum 1 with 6 setae. Wing. Length $2.2 \mathrm{~mm}$, width/length $0.45-0.50$. c/w 080-0.85, R1/R 0.75-0.85. Legs. Length of basitarsomere 1/length of tarsus 10.50 . Tarsal claws without teeth. Abdomen. Yellowish brown. Hypopygium. Fig. 2C and D. Sternite 10 setae not observable in the specimens studied.

Discussion. Bradysia subbetuleti was described based on two males from Russia, Habarovsk region. Up till now no further specimens have been found. We have not seen the type material but based on the original description there is no doubt about the conspecifity of our specimens, provided that no very similar species live in Europe. B. subbetuleti belongs to the welldefined Bradysia nervosa group characterized e.g. by richly setose ventromesial parts of the gonocoxite, roundish-elongated gonostylus without the apical tooth but with uniform mesial setosity at least in the apical half, in some species a group of slender megasetae or at least slightly modified setae mesially, and by long and slender lateral setae on the gonostylus. B. subbetuleti is similar to $B$. diversiabdominalis (Lengersdorf) and B. laurencei Menzel \& Mohrig, $2000=B$. betuleti (Lengersdorf; 1940) sensu Tuomikoski (1960), by having a dense uniform setosity mesially on the gonostylus. $B$. subbetuleti differs from $B$. diversiabdominalis and is similar to $B$. laurencei by having this uniform setosity restricted to the apical half of the gonostylus, not extending far to the basal half, and by having a group of narrow sharp megasetae basad of this setosity. B. subbetuleti differs from $B$. laurence $i$ by having the megasetae more central, not slightly basal on the gonostylus, and by having the gonostylus shorter and with a subapical mesial shallow lobe (see Fig. 2D and Tuomikoski 1960: fig. 30d and Mohrig et al. 1983: fig. 1).

The Finnish specimens are the first of the species from Europe. This kind of apparently disjunct distribution has also been found for other Sciaridae: Camptochaeta tenuipalpalis (Mohrig \& Antonowa, 1978), Claustropyga corticis (Hippa et al. 2003) and Keilbachia ferrata (Hippa \& Vilkamaa 1994), and reflects probably rather inadequate collecting than a real pattern of distribution.

Female unknown.

\section{Ctenosciara exigua sp. $\mathbf{n}$.}

Material examined. Holotype male: Finland, Oa, Kauhajoki, Kauhaneva mire (6911097: 3259448), Swampy tall-sedge fen, Malaise trap, 13.VII.-4.X.2003, J. Salmela (MZH). Paratypes: same locality as holotype, but OligotrophicPapillosum tall-sedge fen, 1 ๙ (PCJS), Tb, Toivakka, Ruostesuo (6886:3443), Malaise trap, 1.VII.-29.VII.2003, J. Salmela, 1 đ (MZH), same data but 30.VIII.-18.X.2003, 1 §ิ (MZH).

Description. Male. Head. Eye bridge with 3 rows of facets. Anterior vertex non-setose, prefrons with 16-22 setae, clypeus non-setose. 


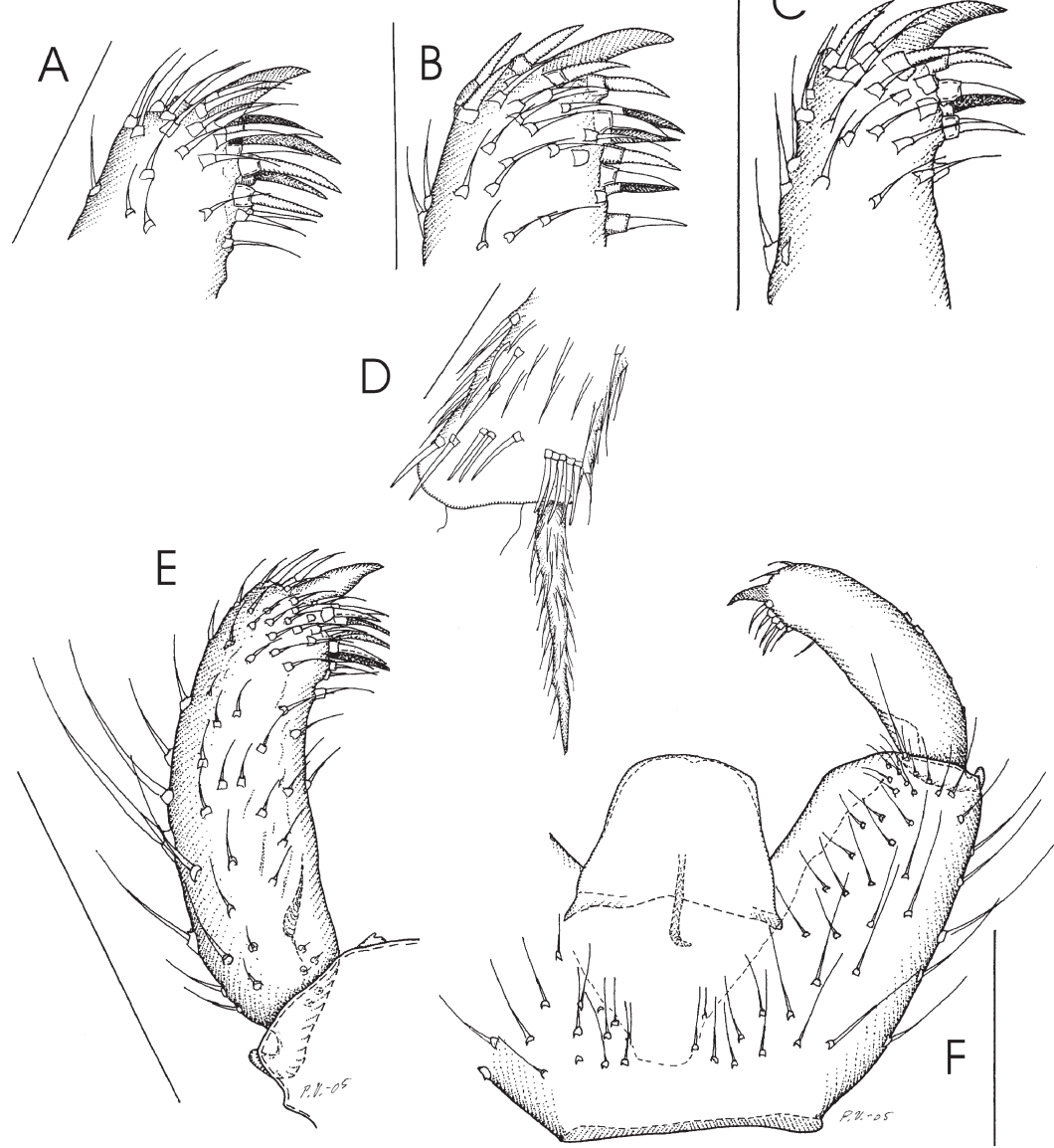

Fig. 3. Apex of gonostylus $(A-C)$, ventral view, apex of front tibia (D), prolateral view, gonostylus (E), and part of hypopygium $(F)$, ventral view. - A. Ctenosciara exigua sp. $\mathrm{n}$. (holotype). - B. C. hyalipennis (Meigen) (from Finland). - C. C. japonica Sutou \& Ito (from Japan). - D-F. Ctenosciara exigua sp. n. (D paratype from Ruostesuo; E-F holotype). Scale bar for A-D 0.05 $\mathrm{mm}$; for E-F $0.10 \mathrm{~mm}$.
Antennal flagellum long; length/width of flagellomere 4 2.80-3.65. Maxillary palp with 3 palpomerees; palpomeree 1 with 2 setae, sensillae in small patch. Thorax. Brown; notal setae pale. Anterior pronotum with 3 setae, episternum 1 with 5-7 setae. Wing. Length $1.6-1.9 \mathrm{~mm}$, width/length 0.45 . c/w $0.70-0.80, \mathrm{R} 1 / \mathrm{R} 0.60$ 0.70. Wing membrane non-setose, R, R1 and R5 with many dorsal setae, R5 with a few ventral setae, $\mathrm{M}$ and $\mathrm{CuA} 1$ with many dorsal setae, $\mathrm{CuA} 2$ with 9-13 dorsal setae, hind margin with dorsal and ventral setae. Legs. (Fig. 3D). Pale. T1 with subapical prolateral two or three-parted comb of pale setae. Tarsal claws with basal teeth. Abdomen. Pale, smaller setae pale, larger brown. Hypopygium. Fig. 3A, E and F. Sternite 10 with 1 seta on each half.

Discussion. Ctenosciara exigua is similar to all other known species of Ctenosciara in having an unmodified gonocoxite, an longated gono- stylus with a sharp apical tooth and a group of subapical megasetae on the mesial side; setose $\mathrm{M}$ and $\mathrm{CuA}$, the fore tibia with a subapical prolateral comb of setae, divided into two (sometimes three) parts, and tarsal claws with teeth.

By the general form of the gonostylus, Ctenosciara exigua is similar to the eastern Palaearctic C. japonica Sutou \& Ito: C. japonica has the gonostylus distinctly attenuated at the apical third, C. exigua has its gonostylus nearly evenly broad or slightly attenuated (Fig. 3A and C, Sutou $\&$ Ito 2003: figure 1). The western Palaearctic $C$. lutea (only the description seen) and especially $C$. hyalipennis have their gonostylus broadened towards the apex. $C$. exigua is similar to $C$. lutea and differs from the other two species mentioned by lacking the megasetae on the dorsal (lateral) side of the apical tooth (Fig. 3A-C). C. exigua differs from $C$. lutea by the shape of gonostylus mentioned above, by being darker and consider- 
ably smaller (length of $C$. lutea ca $4 \mathrm{~mm}$, length of C. exigua at most $2 \mathrm{~mm}$ ) and by having less richly setose $\mathrm{CuA} 1$.

The new species has been collected from Ruostesuo and from the large and fairly pristine Kauhaneva mire system (Kauhaneva-Pohjankangas National Park, western Finland). In the latter locality $C$. exigua was found on a springwater influenced Swampy tall-sedge fen and on an Oligotrophic Papillosum tall-sedge fen. According to the present knowledge, C. exigua is a peatland dwelling species, associated with oligotrophic fens and mesotrophic mires.

Acknowledgements. We thank Frank Menzel (Müncheberg) and Mitsuaki Sutou (Yokohama) for material. PV received funding for the study from the Ministry of the Environment, Finland.

\section{References}

Aapala, K. \& Lindholm, T. (1995) Valtionmaiden suojellut suot (Protected Mires in Finland). - Metsähallituksen luonnonsuojelujulkaisuja, Sarja A 48.155 pp. [[n Finnish, with English summary.]

Dimitrova, B \& Mohrig, W. 1993: Beitrag zur Trauermückenfauna Bulgariens (Diptera, Sciaridae). Teil II. - Acta Zoologica Bulgarica 46: 89-96.

Freeman, P. 1987: British Sciaridae (Diptera): New species and records with notes on the Tuomikoski collection. — Entomologists' Monthly Magazine 123: 195-204.

Frey, R. 1948: Entwurf einer neuen Klassifikation der Mückenfamilie Sciaridae (Lycoridae). - Notulae Entomologicae 27: 33-112.

Heller, K. \& Mohrig, W. 1992: Neue Sciariden (Diptera) aus Schleswig-Holstein. - Entomologische Nachrichten und Berichte 36: 37-42

Hippa, H. \& Vilkamaa, P. 1991: The genus Prosciara Frey (Diptera, Sciaridae). - Entomologica Fennica 2: 113-155.

Hippa, H. \& Vilkamaa, P. 1994: The genus Camptochaeta gen. n. (Diptera, Sciaridae). — Acta Zoologica Fennica 194: 1-85.

Hippa, H. \& Vilkamaa, P. 2004: The genus Xylosciara Tuomikoski (Diptera, Sciaridae): phylogeny and revision of the species. - Acta Zoologica Fennica 214: 138.

Hippa, H., Vilkamaa, P. \& Mohrig, W. 2003: Phylogeny of Corynoptera Winnertz and related genera, with the description of Claustropyga gen. nov. (Diptera, Sciaridae). - Studia dipterologica 9[2002]: 469-511.

International Commission on Zoological Nomenclature [ICZN] 1999: International Code of Zoological Nomenclature. Fourth Edition. - The International Trust for Zoological Nomenclature, London. 306 pp.
Irmler, U., Heller, K. \& Warning, J. 1996: Age and tree species as factors influencing the populations of insects living in dead wood (Coleoptera, Diptera: Sciaridae, Mycetophilidae). - Pedobiologia 40: 134-148.

Komonen, A. \& Vilkamaa, P. 2001: Redescription and biology of Trichosia (Baeosciara) sinuata Menzel \& Mohrig (Diptera, Sciaridae). — Entomologica Fennica 12: 46-49.

Laurence, B. R. 1994: Sciaridae (Dipt.) from East Anglian wetlands, with description of new species. - Entomologist's Monthly Magazine 130: 105-119.

Menzel, F. 1998a: Sciaridae. — In: Chandler, P. J. (ed.), Checklists of Insects of the British Isles (New Series) Part 1: Diptera: 20-24. Royal Entomological Society, London. 234 pp.

Menzel, F. 1998b: Sciaridae. — In: Merz, B., Bächli, G., Haenni, J.-P. \& Gonseth, Y. (eds.): Fauna Helvetica, Diptera-Checklist: 126-130. Schweizerische Entomologische Gesellschaft, Neuchâtel. 369 pp.

Menzel, F. 2000: Die Trauermücken - Fauna der Bundesrepublik Deutschland (Diptera: Sciaridae). Beiträge zur Entomologie 50: 317-355.

Menzel, F. 2001: Sciaridae (Trauermücken). — In: Menzel, F. \& Ziegler, J. (eds.), Neue Funde von Zweiflüglern (Diptera) aus dem National Park Hohe Tauern in Österreich nebst Angaben zum Blütenbesuch und der Beschreibung von zwei neuen Traermücken-Arten (Sciaridae). Studia dipterologica 8: 366-376.

Menzel, F. 2002: Family Sciaridae. — In: Beuk, P.L. (ed.), Checklist of the Diptera of the Netherlands: 64-68. KNNV, Utrecht. 448 pp.

Menzel, F. \& Mohrig, W. 1997: Revision der paläarktischen Arten von Trichosia Winnertz sensu Tuomikoski, 1960 (Diptera, Sciaridae). Teil I. Gattung Trichosia Winnertz, 1867. - Studia dipterologica 4: 3-40.

Menzel, F. \& Mohrig, W. 1998: Beiträge zur Taxonomie und Faunistic der paläarktischen Trauermücken (Diptera, Sciaridae). Teil VI. Neue Ergebnisse aus Typenuntersuchungen und die daraus resultierenden taxonomisch-nomenklatorischen Konsequenzen. Studia dipterologica 5: 351-378.

Menzel, F. \& Mohrig, W. 2000: Revision der paläarktischen Trauermücken (Diptera: Sciaridae). Studia dipterologica Supplement 6[1999]: 1-761.

Menzel, F., Mohrig, W. \& Groth, I. 1990: Beiträge zur Insektenfauna der DDR: Diptera-Sciaridae. - Beiträge zur Entomologie 40: 301-400.

Menzel, F., Smith, J.E. \& Colauto, N.B. 2003a: Bradysia difformis Frey and Bradysia ocellaris (Comstock): two additional Neotropical species of Black fungus gnats (Diptera: Sciaridae) of economic importance: a redescription and review. - Annals of the Entomological Society of America 96: 448-457.

Menzel, F., Schulz, U. \& Taeger, T. 2003b: Neue Trauermücken-Funde aus dem nordostdeutschen Tiefland, mit einer ökologischen Betrachtung von Wurtzelteller-Fängen un einer Checkliste der aus Berlin/ Bradenburg bekanten Arten. - Beiträge zur Entomologie 53: 71-105. 
Mohrig, W., Krivosheina, N. \& Mamaev, B. 1985a: Beiträge zur Kenntnis der Trauermücken (Diptera, Sciaridae) der Sowjetunion. Teil VII. Neue Arten aus dem Amur-Gebiet. - Zoologische Jahrbücher, Abteilung für Systematik, Ökologie und Geografie der Tiere 112: 249-260.

Mohrig, W., Krivosheina, N \& Mamaev, B. 1985c: Beiträge zur Kenntnis der Trauermücken (Diptera, Sciaridae) der Sowjetunion. Teil VIII. Neue Arten aus europäischen Gebieten. - Zoologische Jahrbücher, Abteilung für Systematik, Ökologie und Geografie der Tiere 112: 299-310.

Mohrig, W., Mamaev, B \& Krivosheina, N. 1979: Neue Arten Holzverwertender Sciariden (Diptera) aus der UdSSR. - Zoologische Jahrbücher, Abteilung für Systematik, Ökologie und Geografie der Tiere 106: 572-588.

Mohrig, W., Mamaev, B \& Krivosheina, N. 1985b: Beiträge zur Kenntnis der Trauermücken (Diptera, Sciaridae) der Sowjetunion. Teil IX. Neue Arten aus der Tundra nördlich des Polarkreises. — Zoologische Jahrbücher, Abteilung für Systematik, Ökologie und Geografie der Tiere 112: 429-434.

Mohrig, W., Mamaev, B \& Krivosheina, N. 1987: Beiträge zur Kenntnis der Trauermücken der Sowjetunion (Diptera, Sciaridae). Teil XI. Neue Arten aus der zentralasiatischen autonomen sowjetrepublik Tuwa. -Zoologische Jahrbücher, Abteilung für Systematik, Ökologie und Geografie der Tiere 114: 91-104.

Mohrig, W., Krivosheina, N. \& Mamaev, B. 1989a: Beiträge zur Kenntnis der Trauermücken (Diptera, Sciaridae) der Sowjetunion. Teil XII: Gattung Bradysia, Serie 1. - Zoologische Jahrbücher, Abteilung für Systematik, Ökologie und Geografie der Tiere 116: 411-425.

Mohrig, W., Krivosheina, N. \& Mamaev, B. 1989b: Beiträge zur Kenntnis der Trauermücken (Diptera, Sciaridae) der Sowjetunion. Teil XIII: Gattung Bradysia, Serie 2. - Zoologische Jahrbücher, Abteilung für Systematik, Ökologie und Geografie der Tiere 116: 427-445.

Mohrig, W. \& Menzel, F. 1993: Revision der paläarktischen Arten der Bradysia brunnipes-Gruppe (Diptera, Sciaridae). - Bonner Zoologische Beiträge 44: 267-291.

Mohrig, W. \& Menzel, F. 1994: Revision der paläarktischen Arten von Phytosciara Frey (Diptera: Sciaridae). - Beiträge zur Entomologie 44: 167-210.

Mohrig, W. \& Menzel, F. 1997: Revision der paläarktischen Arten von Trichosia Winnertz sensu Tuomikoski, 1960 (Diptera, Sciaridae). Teil II. Gattungen Leptosciariella Tuomikoski, 1960 und Trichodapus gen. nov. - Studia dipterologica 4: 4198.
Petersen, F.T. \& Meier, R. 2001: A preliminary list of the Diptera of Denmark. - Steenstrupia 26: 119-276.

Rudzinski, H.-G. 1993: Mücken un Fliegen aus dem Schluifelder Moos, Ober-Bayern. Zweite Liste (Diptera Nematocera: Sciaridae). - Entomofauna 14: 281-304.

Rudzinski, H.-G. 1994a: Trauermückenfunde aus NordMähren (Diptera: Sciaridae). — Entomological Problems 25: 11-23.

Rudzinski, H.-G. 1994b: Neue Mitteilungen zur Trauermückenfauna Österreichs (Diptera Nematocera: Sciaridae). - Entomofauna 15: 281-292.

Rudzinski, H.-G. 1996: Neue Trauermückenfunde aus der Türkei (Diptera, Sciaridae). — Entomologische Zeitschrift 106: 108-116.

Rudzinski, H.-G. 1998: Sciaridae. — In: Rozkosny, R. \& Vanhara, J. (eds.), Diptera of the Palava Biosphere Reserve of UNESCO, I. Folia Facultatis Scientiarum Naturalium Universitatis Masarykianae Brunensis Biologia 99: 49-55.

Rudzinski, H.-G. \& Košel, V. 1997: Sciaridae. — In: Chvála, M. (ed.), Check List of Diptera (Insecta) of the Czech and Slovak Republics: 23-24. Charles University Press, Prague. 130 pp.

Rulik, B., Mohrig, W. \& Jaschhof, M. 2001: Trauermücken (Diptera: Sciaridae) und freilebende Gallmücken (Diptera: Cecidomyidae: Lestremiinae) aus Ungarn. Mit Bemerkungen zur Corynoptera tridentata-Gruppe. - Folia Entomologica Hungarica 62: 231-245.

Salonen, V. \& Kovanen, J. 1983: Toivakan Ruostesuon kasvisto ja kasvillisuus sekä suojelumerkitys. Keski-Suomen Seutukaavaliitto, ser. C, 9. 11 pp. +3 appendices. [In Finnish.]

Sutou, M \& Ito, M.T. 2003: A taxonomic study on the genus Ctenosciara (Insecta: Diptera: Sciaridae) from japan. - Species Diversity 8: 1119-1131.

Tuomikoski, R. 1957: Beobachtungen über einige Sciariden (Dipt.), deren Larven in faulem Holz oder unter der Rinde abgestorbener Bäume leben. - Annales Entomologici Fennici 23: 3-35.

Tuomikoski, R. 1960: Zur Kenntnis der Sciariden (Dipt.) Finnlands. - Annales Zoologici Societatis Zoologicae Botanicae Fennicae 'Vanamo' 21(4): 1-164.

Vilkamaa, P. 2000: Phylogeny of Prosciara Frey and related genera (Diptera: Sciaridae). — Systematic Entomology 25: 47-72.

Vilkamaa, P. \& Hippa, H. 2005: Phylogeny of Peyerimhoffia Kieffer, with the revision of the species (Diptera: Sciaridae). — Insect Systematics \& Evolution 35: 457-480.

Vilkamaa, P., Hippa, H. \& Komarova, L. 2004: The genus Dichopygina gen. n. (Diptera: Sciaridae). - Insect Systematics \& Evolution 35: 107-120. 